\title{
VI. Memoir on the tinctorial properties of the danais of commerson, a shrub of the family of the rubiaceæ. Extracted from the Flora of Madagascar. Read in the French National Institute
}

\section{Aubert du Petit-Thouars}

To cite this article: Aubert du Petit-Thouars (1805) VI. Memoir on the tinctorial properties of the danais of commerson, a shrub of the family of the rubiaceæ. Extracted from the Flora of Madagascar. Read in the French National Institute , Philosophical Magazine, 21:81, 35-40, DOI: 10.1080/14786440508676669

To link to this article: http://dx.doi.org/10.1080/14786440508676669

Published online: 17 May 2010.

Submit your article to this journal $\sqsubset$

Џ Article views: 2

View related articles 
VI. Memoir on the Tinatorial Properties of the Danais of Commerson, a Shrub of the Family of the Rubiacece. Extracted from the Flora of Madagascar. By Av вER' $\mathbf{D}_{\text {. }}$ PEtit-Thouars. Read in the French National Institute*

Bo like all the other physical seiences, may be considered under two points of view.' In the first, we examine in plants those things which are perceptible to the senses ; and, by comparing the differences observed, deduce the means of distinguishing them with certainty from each other. In the second, we endeavour to discover the qua-' lities by which they may be useful to man:-the one is pure botany, the other is the application of botany. Most people who have devoted themselves exclusively to une branch of knowledge, or who have not. had an opportunity of acquiring any, being accustomed to judge superficially, value only the second, and consider the first as almost entirely useless. It ought, however, to be considered as the foundation of the second; for, as it alnne establishes, as .we may say, the state of a vegetable, it is by it that we can be assured what plants are capable of giving us that assistance for which we may have occasion. The moment, therefore, that the theoretic botanist seems to attend least to the wants of society, is very often that when he is about to announce an important discovery. Being enabled by an exact synonymy to consult all the books which have been written on the object he examines, he takes advantage of the knowledge of all nations and of all periods. In the second place, if the vegetable he examines have escaped the researches of his predecessors, observation enables him to find out the purpose for which it may be employed. The science which he cultivates affords him still another mean

* From the Fowmal de Pbysique, Brumaire, an 13.

+ This is the third memoir of M. du Petit-Thouars read in the In' stitute since his return. In the first, after a short view of a royage of ten years to the isles of France, Bourbon, and-Madazascar, entifely devoted to the natural sciences, and particulariy botany, he gives a brief description of the deserts of Tristan d'Acugna, which are little frequented by navigators. The second is an essiy on germunation, and the natural relations of the Cycas. This interesting memoir forms part of a first number, which the author has published, and which is to be fo:lowed by swelve more, destined to make known the new ${ }_{2}$ or little know $n$, genera which he had an opporkunty of observing; and which are to be accompanied with dissertations, in the manner of the present one. on interesting points of vegetable physiology. This first number contains also. the description and figures of nine plants, which MI. du Pstit-Thouars ponsiders as forming new genera.

C 2 
of internigating nature; it is the examination of afinities, or the study of natural families; for observation has taught, that, in general, plants which have an' external resemblance in their organization, retain it in the immediate principles of which they are composed. The natural classification, therefore, may sive reason for conjecturing the virtues of a new plant; but, unfortunately, the labour which could give us any certainty in this respect has not been carried to a sufficient length :-to bring it to perfection would require the complete union of a thorough knowledge of botany and chemistry. Hitherto, therefore, the senses of taste and smell have been almost the only guides for discovering in several families, exceedingly natural, one common principle. In the umbelliferous plants, for example, it is traced from plants the most wholesome and the most commonly used for food, such as the carrot, to those which are aromatic, as fennel, and even to poisonous plants, such as hemlock : one observes in ąll these plants a particular taste, more or less' striking, and which is found in its highest degree in those species accounted poisonous. It even appears that the observation of it is sometimes more certain than the common classifications. It is thus that the lagacia could not by these means be separated from the umbelliferous plants, when by its fruit it was referred to them only. with doubtfulness : we must therefore hope that botanists will be able to discover a substance common to all these plants, an umbelliferous principle. In a word, there exists one equally striking in the leguminous plants, from which it passes also, but more rarely, from those that are fit to be eaten to those which are poispnous, when it exists in its'state of greatest concentration.

But there are several other families which seem to be equally natural, and in' which it is difficult to discover a common principle: of this kind are the rubiaceous plants of I ussieu. The signal services derived from a small number of the plants which they comprehend are of a nature so different that it is difficult to deduce a general induction for the rest. Of this kind is madder, the root of which possesses a dyeing quality in so eminent a degree; coffee, the berries of which are so useful ; and, in the last place, cinchona, rendered so valuable by the febrifuge qualities of its bark. Though all the plants comprehended in this family have a greater affuity to each other than they have to any other of the vegetable kingdom, it appears itself to be composed of particular groupes or species of sub-families, and each of the plants I have mentioned may be considered as the type 
of one of them. It may be readily seen that the other plants which accompany each of them, either as belonying to the same genus or as its neighbour, participate more or less in the quality on account of which it is employed. Thus it has been found that almost all the stellate of Ray are tinctorial; almost all the seeds of the neighbouring genera of the coffee shrub, sufficiently large to be torrified with advantage, appear to be of the same nature. The case is the same with cinchoua. I have seen the bark of a beautiful mussenda of the Isle of France employed as a febrifuge by a physician, one of my friends.

These qualities also are seen to pass from one groupe to another. It is thus that the Indians extraet the beautiful red colour of the chailliver, which, according to Adanson, was a hedyotis, and which Roxburgh has described as an oldenlàndia. They extract also a red colour from the royoc or morinda. The cinchonas themsêlves have given colours. Some of their particular properties bave been found also in shrubs which had a very distant relation to them. The psychotria emetica approaches near to some of those which have been found to be emetic. The antirrhea of Commerson; or wood of the losieau, participates in the anti-dysenteric quality of the last-mentioned plant. In a word, according to Gærtner and several others, a kind of coffee has been extracted from the seeds of the aparine:

Other properties less extensive in one groupe have others analugous to them in another. Thus the pretty species of the mussenda, which Commerson named, after his countryman, Lalandia stelliftora, has a relation to the asperula odorata.' Its dricd leaves, like those of that plant, acquire an agreeable odour, on which account they are put among linen: on the other hand, the fetid and cadaverous odour of the poederia is found in the serissa of Jussieu, or the dysoda of Loureiro, and in the fruit of some kinds of $p y-$ rostria.

However vague these indications may be, they may serve as guides in experiments; and though one cannot previously assert that a rubiaceous plant possesses any of its properties, one will not be surprised to find them in it. When I was in Madagascar, in 1795, I saw without astonishment the natives of the country extract, from the root of a rubiaceous plant, the red dye they employed for the cloth which they wore of thread, made from the tafia palm. I readily knew it to be a creeping shrub, common in the elevated places of the Isle of France. 
On my return to the Isle of France, I proposed to make some experiments in regard to the utility it might be of in giving an intense and fixt colour; 'but having no apparatus, and being unprovided with books which might point out the process I ought to follow, I could only make a few trials, which convinced me of its utility, but they were not sufficient to indicate the method of using it. They exhibited one phrnomenon which was very remarkable; it is not, however, peculiar to this plant, for it is found in another vegetable, but which has so little relation to the one in question, and exhibits it in a part so different, that the conformity itself is still another singularity. But before 1 describe it, I must speak of the plant.

It has been described by Commerson, and is found in his herbals. This naturalist, whose premature death was sensibly felt by all those' who cultivate the sciences, besides his knowledge, thad a particular instinct in the application of names. 'Observing that this plant was dicecous by abortion, so that the stamina seemed to be choked by the pistil, he compared it to the Danaides, which put to death their husbands, and thence gave it the name of Danais; he was not able to procure any of its fruit. The fruit being the important character of this family, it was impossible for him to determine its place with precision; and Jussiet and Lamarck united it to the poederia. The latter, in his Dictionary, calls it the odoriferous danais, because its flowers, according to the remark of De Court, are exceedingly odoriferous, and of a beautiful orange colour. These two naturalists having afterwards procured some of its fruit, found that they had two cells, each containing several seeds, and consequently that it differed from the poederia, which-had only two. Having an opportunity of seeing them in all theirstates, I observed the same tiling; and finding also that the seeds were bordered by a membranous circle, il considered it as a species of cinchona: but it appears that there are several peculiar characters in the internal construction of the capsule, and its manner of opening, which renders it necessary to restore the genus of Commerson, and this is confirmed by the difference of appearance; but it ought $t o$ be placed between the mussenda and the cinchona, and very near to the latter. I discovered four species which belong to this genus; the present is the only one which I found to possess the tinctorial quality: a description of them here would be misplaced, they will form part of my Flora. I shall at present confine wiyself to an account of 
the few experiments which I made, to point out the route to some one more successful who may be able to determine the means of employing it.

Having pulled up the roots of this plant, I was much surprised to see them of an orange colour, inclining rather to yellow than to red: the rind was pulpy and succulent. Having cleaned them, I put some pieces of it into spirit or rack extracted from the sugar of the country, which in a little time became charged with a tincture of a very pure yellow. When it appeared to me that it had extracted all it could, I poured it into a saucer; the pieces of the root were then of a beautiful red colour: having poured more rack over them, some more particles of yellow were extracted, but it became still redder, and this colour continued unalterable, though I suffered the liquor to remain over them several days. What I poured into the saucer having evaporated, the residuum was of a very beautiful yellow colour. For want of other means, I contented muself with rubbing it over paper. Being desirous to try whether a pigment proper for water colours could be extracted from it, I mixed it with gum arabic: it spread very well on the psper; I tasted also the extract, it had the bitterness of cinchona in such a degree as gave me reason to hope that it may be rendered of utility in this point of view.

Having tried this root with spirit of wine, I put some of it fresh into pure water. By ebullition the water became charged in like manner with the yellow colouring principle, which it extracted entirely: the root also assumed a red colour, which could no longer be attacked by water. One of my friends had given me a small quantity of a solution of tin in the nitric acid; I poured a few drops of it into the liquor I had obtained, and they precipitated all the colouring parts suspended in it. Having decanted the water, the residum was of a beautiful yellow colour: I hoped I should obtain from it a kind of Dutch pink : I therefore poured more water over it to wash it, but the water, thougls cold, took up all the colour: nothing then remained at the bottom of the vessel but oxide of tin cxceedingly white.

I learned at Madagascar that the process employed by the natives, and probably from time immemorial, to obtain a red colour, is to boil the root with ashes: I thence presumed that alkalis were its solvent, but at that time $I$ was unable to procure any; I contented myself, therefore, with boiling it in alum; the two colours were then perceptible; the yellow appeared first, and then the red : at first very

$$
\text { C. } 4
$$

listile 
little mixed, but afterwards combined, which formed the colour of a fawn's beily, exceedingly beautiful. These were all the experiments I was able to make. They are sufficient to show the relation between this plant and the carthamus : its flowers give in like manner a yellow colour; and the beautiful red which they produce becomes purer in proportion as it is separated. I wish I could present results more satisfactory; but, being buffeted by circumstances, $I$ was seldom able to carry my plans into execution; and in regard to many other objects I have nothing left but regret : but I easily console myself when I reflect, that I shall be exceedingly happy if 1 can publish what $I$ have left of ten years' observations made in a field almost new.

Since this memoir was written, having had an opportunity of observing the asperula tinctoria, I remarked that its roots exhibit the same colour as those of the danais. Having put them into spirit of wine they gave also a yellow colour, but not so pure as that of the danais. I obtained the same thing from the rubia tinctorum; and I have since learned that it had been observed that these plants give two colours, according as they are treated; which still tends to confirm the analogy I have announced.

VII. Olservations on the Change of some of the proximate Principles of Vegetalles into Bitumen; with analytical Experiments on a peculiar Sulstance which is found with the Bovey Coal. By Charles Hatchetr, Esq. F.R.S.*

\section{$\S \mathrm{I}$.}

$\mathrm{O}_{\mathrm{NE}}$ of the most instructive and important parts of geology, is the study of the spontaneous alterations by which bodies formerly appertaining to the organized kingdoms of nature have, after the loss of the vital principle, become gradually converted in to fossil substances.

In some cases this conversion has been so complete as to. destroy all traces of previous organic arrangement ; but in others the original texture and form have been more of less preserved, although the substances retaining this texture, and exhibiting these forms, are often decidedly of a mineral nature. Some, however, of these extraneous fossils (as they are called) retain part of their original substance or principles, whilst others can only be regarded as casts or impressions.

r From the Tiansactions of the Riyn' Suciety of London for 3804 . 